\title{
PENYULUHAN MANAJEMEN BUDIDAYA IKAN PADA USAHA DAGANG DI KOTA PALANGKA RAYA
}

(The Counseling of Cultivation Fish Management in Trade Bussiness in Palangka Raya City)

lin Nurbudiyani, Endang Sri Suyati dan Santi Endriani

\author{
Program Studi Pendidikan Ekonomi Fakultas Keguruan dan IImu Pendidikan \\ Universitas Muhammadiyah Palangkaraya \\ JI. RTA Milono Km.1,5 Palangka Raya, Kalimantan Tengah 73111 \\ e-mail : innurbudiyani11@gmail.com \\ endangsuyati@yahoo.co.id \\ endrianisanti@gmail.com
}

\begin{abstract}
Management must be keen in making decisions, especially regarding sales. The purpose of this activity is to provide information to the community, especially the fish cultivations in the town of Palangka Raya on the management of fish cultivation as a material consideration in decision making in order to increase its profits. Implementation of the activities carried out by providing counseling to residents fish cultivations and a number of students who participate in these activities.

Community service is implemented by budget on Year 2015. Community service was implemented during 2 (two) months and the providing counseling implemented one fullday at $07.00 \mathrm{pm}$ until $17.00 \mathrm{pm}$. Activities begin with the opening, provision of material and followed by discussion and questions. The material presented in this counseling regarding information on how aquaculture, which produces high value, include; corporate management, financial management and marketing management.

This activity was successfully implemented for their excellent response and high motivation of the participants as well as can be seen from the presence of ladies and gentleman and teenagers who are developing fish cultivations on the home page or in land they had prepared.
\end{abstract}

Keywords: fish cultivations, information management, decision making

\begin{abstract}
Abstrak
Manajemen harus bersifat tajam dalam mengambil keputusan khususnya mengenai kegiatan "penjualan". Tujuan pelaksanaan kegiatan pengabdian kepada masyarakat ini adalah memberikan bekal dan informasi kepada masyarakat khususnya para pembudidaya ikan di Kota Palangka Raya tentang manajemen berbudidaya ikan sebagai bahan pertimbangan dalam pengambilan keputusan untuk meningkatkan keuntungan (laba) usaha budidaya ikan. Pelaksanaan kegiatan pengabdian kepada masyarakat dilakukan dengan memberikan penyuluhan kepada warga pembudidaya ikan dan beberapa mahasiswa yang ikut serta berpartisipasi dalam kegiatan ini.

Kegiatan pengabdian kepada masyarakat ini dilaksanakan menggunakan anggaran pada tahun 2015. Pengabdian kepada masyarakat ini dilaksanakan selama dua bulan dan penyuluhannya dilakukan selama satu hari penuh dimulai pukul 07.00 sampai 17.00 WIB. Kegiatan penyuluhan dimulai dengan pembukaan, penyampaian materi dan dilanjutkan dengan diskusi serta tanya jawab. Materi yang disampaikan dalam penyuluhan ini mengenai informasi bagaimana cara budidaya ikan yang menghasilkan nilai jual yang tinggi, meliputi : manajemen pengelolaan, manajemen keuangan dan manajemen pemasaran.

Kegiatan ini berhasil dilaksanakan karena adanya respon yang sangat baik dan motivasi yang tinggi dari peserta serta dapat dilihat dari kehadiran bapak-bapak dan ibu-ibu bahkan remaja yang sedang mengembangkan budidaya ikan di halaman rumah maupun di lahan yang sudah mereka siapkan.
\end{abstract}

Kata kunci : budidaya ikan, informasi manajemen, pengambilan keputusan 


\section{PENDAHULUAN}

\section{Analisis Situasi}

Indonesia sebagai negara kepulauan mempunyai potensi sumberdaya ikan yang sangat melimpah. Pembangunan sektor perikanan selain sebagai penyokong kebutuhan protein hewani bagi masyarakat juga membuka lapangan kerja, menambah pendapatan masyarakat dan sebagai sumber devisa negara.

Seiring dengan meningkatnya jumlah populasi, konsumsi ikan pun dari tahun ke tahun pun semakin meningkat. Ditambah lagi pada tahun-tahun terakhir ini ekspor ikan Indonesia ke luar negeri juga berjalan lancar dengan grafik yang meningkat. Dunia usaha perikanan di negara kita menjanjikan masa depan yang cerah bagi para pengusaha. Banyak orang mulai melirik dunia bisnis perikanan, akan tetapi tidak sedikit takut terhadap resiko kegagalan ditambah dengan minimnya pengetahuan bisnis tentang perikanan dan kemudian banyak yang ragu untuk terjun ke bisnis ini.

Manajemen perikanan merupakan tantangan sekaligus kewajiban, mengingat secara alamiah Indonesia sebagai negara kepulauan yang dikaruniai potensi sumber daya perikanan yang cukup. Manajemen dimaksud mencakup manajemen komponen biofisik ekosistem dan manajemen kegiatan perikanan. Manajemen dapat berupa jumlah dan ukuran ikan yang ditangkap serta waktu melakukan penangkapan. Pihak pengusaha dalam menjalani usahanya dihadapkan pada pengambilan keputusan. Menyikapi kondisi seperti ini, manajemen memerlukan informasi akuntansi deferensial yang dapat dijadikan pertimbangan agar didapatkan program yang efektif dan efisien. karena itulah perlu dilakukan sosialisasi langsung kepada masyarakat, khususnya masyarakat yang sedang mengembangkan budidaya ikan di halaman rumah maupun di lahan yang sudah mereka siapkan.

Tujuan budidaya perikanan bagi masyarakat umumnya untuk mendapatkan produksi perikanan yang lebih baik atau lebih banyak dibandingkan dengan hasil dari ikan yang hidup di alam secara liar. Faktor-faktor yang perlu diperhatikan dalam budidaya perikanan antara lain:

a. Penyediaan benih, benih yang baik dan berkualitas unggul sangat penting untuk memperoleh produksi yang tinggi.

b. Pembuatan tempat pemeliharaan, luas tempat yang disediakan untuk pembudidayaan harus sesuai dengan jumlah populasi yang ditebar, tidak kalah penting yang harus dilakukan adalah untuk memahami karakteristik dan tingkah laku ikan.

c. Pengairan, tanpa sistem pengairan yang baik tidak mungkin usaha perikanan bisa berhasil. Oleh karena itu kebersihan air dan debit yang cukup, penting demi kelancaran pemeliharaan. Pintu saluran air perlu selalu diperiksa untuk mengatur pengeluaran dan pemasukan air.

d. Pakan dan pemupukan, peranan pakan sangat penting untuk meningkatkan produksi. Kandungan gizi pakan lebih berperan dibandingkan dengan jumlah yang deberikan. Usahakan memberi pakan sesuai dengan kebutuhan, jangan kebanyakan atau kekurangan. Baru-baru ini banyak digalakkan menggunakan pakan alami, karena ramah lingkungan. 
e. Pengendalian hama dan penyakit, untuk membasmi hama yang hidup di air, dapat digunakan bahan pestisida organik, seperti tepung biji teh yang mengandung senyawa saponin, akar tuba yang mengandung senyawa rotenon, atau tembakau yang mengandung senyawa nikotin. Hal yang penting untuk pengendalian hama dan penyakit ini yaitu perawatan dan pemeliharaan kesehatan air serta kebersihan lingkungan di sekitar kolam.

Manajemen adalah sebuah proses yang dilakukan untuk mewujudkan tujuan melalui rangkaian kegiatan berupa perencanaan, pengorganisasian, pengarahan dan pengendalian sumber daya manusia dan juga sumber daya alam. Dalam melakukan kehidupan sehari hari kita sebenarnya tidak akan pernah lepas dari suatu manajemen, baik itu dunia pekerjaan, pendidikan, kesehatan, penelitian dan lain lain. Sebaik apapun potensi yang kita miliki tetapi jika tidak di ikuti oleh manajemen yang baik maka hasilnya kurang baik, sebaliknya jika potensi kita biasa biasa saja tetapi jika di atur oleh manajemen yang baik maka hasilnya akan lebih baik. Demikian pula dalam dunia tata kelola bisnis perikanan, manajemen diperlukan tentunya agar bisnis dapat berjalan lancar dan mendapatkan hasil yang diharapkan.

Donald W. Kroeber mendefinisikan Informasi manajemen adalah sistem informasi yang dibutuhkan sebuah organisasi dengan pengolahan seluruh transaksi yang mendukung fungsi manajemen dalam pengambilan sebuah keputusan. Informasi manajemen meliputi metode dan upaya yang terorganisasi dalam menjalankan fungsi pengumpulan data, baik dari dalam atau dari luar organisasi dan menggunakan komputer dalam prosesnya untuk bisa menghasilkan dan menyajikan informasi kekinian, akurat, tepat, serta cepat untuk semua pihak yang berkepentingan dalam pengambilan sebuah keputusan manajemen.

Pengambilan keputusan (desicion making) adalah melakukan penilaian dan menjatuhkan pilihan. Keputusan ini diambil setelah melalui beberapa perhitungan dan pertimbangan alternatif. Sebelum pilihan dijatuhkan, ada beberapa tahap yang mungkin akan dilalui oleh pembuat keputusan. Tahapan tersebut bisa saja meliputi identifikasi masalah utama, menyusun alternatif yang akan dipilih dan sampai pada pengambilan keputusan yang terbaik.

\section{Permasalahan}

Prospek dunia usaha sektor perikanan di negara kita menjanjikan masa depan yang cerah bagi masyarakat dan para pengusaha. Banyak masyarakat mulai melirik dunia bisnis perikanan ini, tetapi banyak yang takut terhadap resiko kegagalan dikarenakan minimnya pengetahuan bisnis tentang manajemen berbudidaya maupun teknis perikanan dan kemudian banyak yang ragu untuk terjun ke bisnis usaha perikanan ini.

\section{Tujuan}

Tujuan pelaksanaan kegiatan pengabdian kepada masyarakat ini adalah memberikan bekal dan informasi kepada masyarakat dalam bentuk penyuluhan khususnya kepada para pembudidaya ikan di Kota Palangka Raya tentang manajemen berbudidaya ikan sebagai bahan pertimbangan dalam pengambilan keputusan untuk meningkatkan keuntungan (laba) usaha budidaya ikan. 


\section{METODE PELAKSANAAN}

\section{Waktu dan Tempat}

Kegiatan pengabdian kepada masyarakat ini adalah memberikan bekal dan informasi kepada masyarakat dalam bentuk penyuluhan khususnya kepada para pembudidaya ikan. Pengabdian kepada masyarakat ini secara keseluruhan tahapannya dilaksanakan selama 2 (dua) bulan dari bulan November sampai Desember 2015. Pelaksanaan penyuluhan dilakukan satu hari penuh dimulai pukul 07.00 sampai 17.00 WIB yang dipusatkan di TK 'Aisyiyah Bustanul Athfal 1 di Jalan RTA Milono Km. 7,5 Palangka Raya. Kegiatan pengabdian kepada masyarakat ini dilaksanakan di wilayah Kota Palangka Raya yang mengundang masyarakat sekitar kampus yang meliputi masyarakat pembudidaya ikan dan mahasiswa yang menggeluti pembelajaran dan pelaku manajemen usaha (wirausaha) di wilayah Kota Palangka Raya.

\section{Sasaran Kegiatan}

Masyarakat sasaran kegiatan pengabdian kepada masyarakat ini adalah sesuai dengan pencapaian tujuan kegiatan ini yaitu 1). masyarakat para pembudidaya ikan di wilayah Kota Palangka Raya, dan 2) mahasiswa Program Studi Pendidikan Ekonomi FKIP UM Palangkaraya yang menekuni pembelajaran manajemen usaha (wirausaha).

\section{Metode Kegiatan}

Metode kegiatan pengabdian kepada masyarakat ini dilakukan dengan beberapa tahapan sebagai berikut :

a. Persiapan kegiatan, penyusunan proposal dan penelusuran pustaka; b. Observasi lapangan tentang masyarakat pembudidaya ikan dan mahasiswa pembelajar dan pelaku manajemen usaha (wirausaha);

c. Identifikasi sasaran calon peserta penyuluhan;

d. Pembuatan dan pengadaan bahan penyuluhan (materi dan peraga dan bahan simulasi);

e. Proses mengundang dan kesediaan sasaran peserta penyuluhan;

f. Pelaksanaan penyuluhan penyampaian materi, diskusi dan tanya jawab serta penyusunan rumusan;

g. Evaluasi kegiatan dan tindaklanjut penyuluhan;

h. Penyusunan laporan penyuluhan dan publikasi artikel ilmiah kegiatan pengabdian kepada masyarakat.

\section{Solusi yang Ditawarkan}

Solusi yang ditawarkan pada kegiatan pengabdian kepada masyarakat ini adalah :

a. masyarakat mendapatkan informasi dan motivasi mengenai sektor perikanan sebagai sektor yang menjanjikan di masa depan bagi masyarakat dan para pengusaha,

b. masyarakat mempunyai ketertarikan dalam bidang dunia bisnis perikanan,

c. masyarakat mempunyai pengetahuan bisnis tentang manajemen berbudidaya maupun teknis perikanan sehingga memiliki manajemen resiko dalam bisnis usaha perikanan,

d. masyarakat mendapatkan bekal dan informasi dalam bentuk penyuluhan tentang manajemen berbudidaya ikan secara baik,

e. masyarakat mendapatkan bekal dan informasi dalam bentuk penyuluhan tentang pemasaran dalam pengambilan keputusan untuk meningkatkan keuntungan (laba) usaha budidaya ikan. 


\section{HASIL DAN PEMBAHASAN}

Kegiatan pengabdian kepada masyarakat ini dilaksanakan dengan memberikan bekal dan informasi serta dampingan kepada masyarakat pembudidaya ikan maupun masyarakat umum termasuk mahasiswa yang tertarik usaha budidaya ikan. Pengabdian kepada masyarakat ini dilengkapi dengan upaya penyuluhan yang pelaksanaannya dipusatkan di TK 'Aisyiyah Bustanul Athfal 1 di Jalan RTA Milono Km. 7,5 Palangka Raya karena letaknya tidak jauh dari peserta para pembudidaya ikan dan dapat terjangkau dengan mudah oleh para peserta pengabdian. Materi yang disampaikan dalam penyuluhan ini mengenai informasi bagaimana cara budidaya ikan yang menghasilkan nilai jual yang tinggi, meliputi : manajemen pengelolaan, manajemen keuangan dan manajemen pemasaran. Kegiatan selanjutnya adalah diskusi, tanya jawab dan evaluasi pemahaman peserta tentang materi yang telah disampaikan serta dilengkapi dengan simulasi teknik budidaya ikan khususnya budidaya ikan lele yang potensial dikembangkan di kota Palangka Raya.

Pengabdian kepada masyarakat ini mengawal pembudidaya ikan dari sisi manajemen usaha. Tim pengabdian kepada masyarakat yang berasal dari Dosen Program Studi Pendidikan Ekonomi Universitas Muhammadiyah Palangkaraya menyampaikan berbagai pembahasan mengenai manajemen yang baik dan efisien pada usaha budidaya ikan. Penyampaian materi oleh lbu Dr. lin Nurbudiyani, M.Pd, Ibu Endang Sri Suyati, M.Pd dan Ibu Santi Endriani, M.Sc dilakukan dan dikemas secara audio visual, Tanya jawab, dan diskusi. Akhir penyampaian juga diberikan gambaran simulasi usaha budidaya ikan dan teknisnya yang disampaikan oleh 1 (satu) orang dosen dari PGSD UM Palangkaraya yaitu Bapak Dedy Setiawan, M.Pd dan 1 (satu) orang dosen dari Bimbingan Konseling UM Palangkaraya yaitu Bapak Andi Riswandi Buana Putra, M.Pd yang secara teknis menyampaikan salah satu usaha budidaya ikan lele sebagai usaha alternatif peningkatan pendapatan rumah tangga yang strategis.

Kegiatan ini berhasil dilaksanakan karena adanya respon yang sangat baik dan motivasi yang tinggi dari peserta pengabdian kepada masyarakat yang dapat dilihat dari kehadiran bapak-bapak dan ibu-ibu bahkan remaja yang sedang mengembangkan budidaya ikan di halaman rumah maupun di lahan yang sudah mereka siapkan.

\section{SIMPULAN DAN SARAN}

\section{Simpulan}

Kegiatan pengabdian kepada masyarakat ini berhasil dilaksanakan karena adanya respon yang sangat baik dan motivasi yang tinggi dari peserta serta dapat dilihat dari kehadiran bapakbapak dan ibu-ibu bahkan remaja yang sedang mengembangkan budidaya ikan di halaman rumah maupun di lahan yang sudah mereka siapkan.

Kegiatan pengabdian kepada masyarakat ini berhasil dilaksanakan dengan membekali dan menginformasikan teknis budidaya ikan, manajemen pengelolaan perikanan, manajemen keuangan perikanan dan manajemen pemasaran perikanan, meskipun belum menyampaikan tentang teknologi pengolahan hasil perikanan. 


\section{Saran}

Kegiatan pengabdian kepada masyarakat ini menghasilkan saran, bahwa:

a. Kegiatan pengabdian kepada masyarakat ini diharapkan dapat dilaksanakan secara berkelanjutan ke organisasi dan atau kelompok pembudidaya di masyarakat, tidak hanya operasionalisasi organisasi bahkan diharapkan dapat mengembangkan teknologi budidayanya beserta cara pemasaran.

b. Disarankan adanya penyuluhan dan pelatihan pengelolaan perikanan yang baik dan dapat dikembangkan dengan produk-produk olahan lain berupa bakso ikan, krupuk ikan dan lainlain yang berbahan dasar ikan didapat dari hasil budidaya sendiri karena lebih menguntungkan bagi yang mengembangkan usahanya.

c. Diharapkan pihak lembaga khususnya LP2M dapat terus mendukung kegiatan pengabdian masyarakat ini, kalau memungkinkan pelaksanaannya dua kali dalam setahun.

d. Dengan seringnya melakukan pengabdian masyarakat maka akan lebih banyak lagi jumlah mahasiswa yang terlibat dalam kegiatan pengabdian kepada masyarakat dan belajar mengaplikasikan ilmunya kepada masyarakat dan dapat meningkatkan pengetahuan serta kesadaran untuk dapat berwirausaha akan lebih meningkat.

\section{UCAPAN TERIMA KASIH}

Ucapan terima kasih disampaikan kepada Universitas Muhammadiyah Palangkaraya yang telah memfasilitasi dan membantu pendanaan pembiayaan kegiatan pengabdian kepada masyarakat pada Tahun Anggaran 2015. Terimakasih juga disampaikan kepada masyarakat pembudidaya ikan dan mahasiswa yang yang secara aktif berpartisipasi pada kegiatan pengabdian kepada masyarakat ini.

\section{DAFTAR PUSTAKA}

Halim, Abdul., Bambang, Supomo., Kusufi, Syam Muhammad. 2013. Akuntansi Manajemen. Edisi ke Dua. BPFE, Yogyakarta.

Simamora, Henry. 2012. Akuntansi Manajemen. Edisi III. Star Gate Publisher. Duri, Riau.

Supriyono. 2001. Akuntansi Manajemen 3: Proses Pengendalian Manajemen Edisi 1. Yogyakarta: STIE YKPN.

Sutrisno, Hadi. 1996. Metodologi Research I. Yogyakarta: Andi Ofset.

Ticoalu, Nancy. 2014. Penerapan Informasi Akuntansi Deferensial Dalam Pengambilan Keputusan Terhadap Pesanan Khusus Pada UD. Vanela. Jurnal EMBA. No. I. Vol.2. 